\title{
Mitochondrial DNA-based diversity study of Hungarian brown hares (Lepus europaeus Pallas 1778)
}

\author{
Noémi Soós-Szilvia Kusza \\ University of Debrecen Faculty of Agricultural and Food Sciences and Environmental Management, \\ Institute of Animal Science, Biotechnology and Nature Conservation, Debrecen \\ soos.noemi@agr.unideb.hu
}

\begin{abstract}
SUMMARY
The brown hare being an important game species which is widespread across the European continent has been in focus of many population genetic studies. However only a few comprising researches can be found on the diversity of Central-European populations.

The aim of our large scale long term ongoing study is to fill this gap of information on the species by describing the genetic history and structure of the brown hare populations of the area using both mitochondrial DNA markers and genomic skin and hair colour regulating genes.

This article gives forth a part of our results concerning the mitochondrial DNA diversity of Hungarian brown hares based on amplification of a 512 bp long D-loop sequence. N=39 tissue or hair samples have been collected from 15 sampling sites on the Hungarian Great Plain. We have described a high level of haplotype diversity $(H d=0.879 \pm 0.044)$ based on a $410 \mathrm{bp}$ alignment of our sequences. We have found 17 haplotypes within our sample set with the nucleotid diversity of $\pi=0.01167 \pm 0.0022$. Our ongoing research shows high genetic diversity for the brown hare in the studied region and a second alignment with 156 sequences downloaded from GenBank indicates a geographic pattern of haplotypes among the studied populations though these results need confirmation by our further analyses.
\end{abstract}

Keywords: diversity, Hungary, Lepus europaeus, mitochondrial DNA, D-loop

\section{ÖSSZEFOGLALÁS}

A mezei nyúl egy Európa szinte minden területén elterjedt, vadászati szempontból kifejezetten fontos emlösfaj, ezért az utóbbi évszázadban sok kutatás foglalkozott populációgenetikai jellemzöinek feltárásával és filogeográfiája leirásával. Ennek ellenére a közép-európai populációkról nagyon keveset tudunk.

Hosszú távú, nagyszámú mintát alapul vevö kutatásunk célja, hogy e fehér foltot megszüntesse a faj populációgenetikai ismeretanyagának térképén. Ezen kutatásban négy genetikai markert használva tervezzük feltérképezni a közép-európai populációk diverzitását, populációgenetikai szerkezetét. Jelen munkában a mtDNS D-loop régiójának egy 512 bázispár hosszú szakasza amplifikálása alapján végzett munka eredményeit tesszük közzé

$N=39$ szövet- vagy szörmintát dolgoztunk fel, melyek az Alföld 15 mintavételi helyéröl származnak. A kapott szekvenciák 410 bázispár hosszú illesztése alapján 17 haplotípust írtunk le magas haplotípus diverzitás $(H d=0,879 \pm 0,044)$ értékkel. A nukleotid diverzitás $\pi=0,01167 \pm$ 0,0022 értékünek adódott. Elözetes vizsgálataink magas genetikai diverzitást, valamint egy második, 156 GenBank-röl származó szekvenciát is magában foglaló illesztés alapján földrajzi mintázatot mutatnak, bár ez utóbbi eredmény további analizissel való megerösitést kíván.

Kulcsszavak: diverzitás, Magyarország, Lepus europaeus, mitokondriális DNS, D-loop

\section{INTRODUCTION}

Among other effects the severe and multiple climatic changes in the Pleistocene epoch are the most important reasons why the diversity and distribution of most European mammal species show their contemporary characteristics. That is the case concerning the European brown hare (Lepus europaeus Pallas 1778) also (Hewitt 1999, Kasapidis et al. 2005, Alves et al. 2008). In addition, the brown hare's natural populations suffer from the effects of hybridization with other species of the genus, the fragmentation of natural habitats and because of the latter from the competition for the continually decreasing food resources (Tapper and Barnes 1986, Endler and Jezierski 1995, Panek and Kamieniarz 1999, Koutsogiannouli et al. 2014.).

The L. europaeus is native and present on the majority of the European continent (Folitarek 1940, Thenius 1980) and is a highly important game species which make it an obvious subject for different population genetic studies. Many research groups focused on its evolutionary history (e.g. Kasapidis et al. 2005, Stamatis et al. 2009, Antoniou et al. 2013) but there is a lack of consensus among them regarding the possible glacial refugia and the directions of the postglacial expansion. For instance Stamatis et al. (2009) described one major refugium area on the Balkans while other researchers have presented works which suggest that multiple refugia were present in the Mediterranean Basin (Kasapidis et al. 2005, Fickel et al. 2008) including one on the Iberian-peninsula.

Mitochondrial DNA based (typically D-loop and cytochrome-b) population genetic analyses have provided a great amount of data on the brown hare (e.g. Alves et al. 2003, Djan et al. 2006, Stamatis et al. 2009, Mamuris et al. 2010) showing different degrees of genetic divergence within and among the populations of Europe. Despite the fact that the species is so well-studied on the whole continent we have very few information about its populations in Central- and Eastern-Europe.

This is the reason why we have started a project on brown hares of the abovementioned area. Our main objectives are to investigate the diversity and phylogeography (along with possible glacial refugia) and to describe genetic relationships between the populations of the species in Central-Europe. 
We plan to carry out our research on as many individuals as we can during the research period of which there are 179 collected so far. Beside the mtDNA D-loop and cyt $b$ regions we intend to focus on the MC1R and ASIP genes as well since there can be found a large amount of data in the literature on those also (Fontanesi et al. 2006, Fontanesi et al. 2010, Koutsogiannouli et al. 2012). In this article we provide preliminary results of our research on the Central- and Eastern-European hare populations' mtDNA diversity.

\section{MATERIAL AND METHODS}

\section{Sample collection}

Our 39 samples (tissue and hair) have been collected from 15 sampling sites of the Great Hungarian Plain: Detk, Kápolna, Erk, Dormánd, Négyes, Mezőnagymihály, Mezőcsát, Hajdúnánás, Hortobágy, Balmazújváros, Túrkeve, Körösszegapáti, Kötegyán, Békéscsaba and Baja (Figure 1). Some of them were provided by hunters during the hunting seasons of 2010-2014, while others have been found in 2015, in Imperial eagles' nests by the co-workers of the Hungarian Ornithological and Nature Conservation Society (MME) during nest monitoring in connection with the ,Conservation of Imperial eagles in Hungary” (LIFE10NAT/HU/019) project.

DNA from tissue samples was isolated with and following the instructions of the E.Z.N.A. ${ }^{\circledR}$ Tissue DNA Kit (Omega Bio-Tek), while from hair follicles we isolated the DNA with simple proteolysis using ProteinaseK from Tritirachium album of Sigma-Aldrich's following the protocol of FAO/IAEA (2004).

For the amplification of a 512 base pairs long sequence of the mtDNA D-loop region we used the primers (Le.H-Dloop, Le.L-Dloop) published by Kasapidis et al. in 2005. The PCR was carried out under the thermal conditions listed in Table 1 with 35 reaction cycles.

PCR program thermal conditions used in this study

\begin{tabular}{lll}
\hline Initial denaturation & $94^{\circ} \mathrm{C}$ & $5 \mathrm{~min}$ \\
Denaturation & $94{ }^{\circ} \mathrm{C}$ & $1 \mathrm{~min}$ \\
Annealing & $60^{\circ} \mathrm{C}$ & $1 \mathrm{~min}$ \\
Elongation & $72^{\circ} \mathrm{C}$ & $1 \mathrm{~min}$ \\
Final elongation & $72^{\circ} \mathrm{C}$ & $5 \mathrm{~min}$ \\
\hline
\end{tabular}

The electrophoretic pattern was visualized using ethidium bromide in 2\% agarose gel. PCR product purification and sequencing have been carried out as a service by Macrogen Europe.

\section{Sequence analysis}

For sequence alignment we used CodonCode Aligner v.6.0.2 (CodonCode Corporation, www.codoncode. com) and then re-checked with the naked eye. One of our aims was to allocate the Hungarian brown hare population in the European phylogeography therefore we downloaded sequences of $L$. europaeus mtDNA

Figure 1: Map of the sampling sites

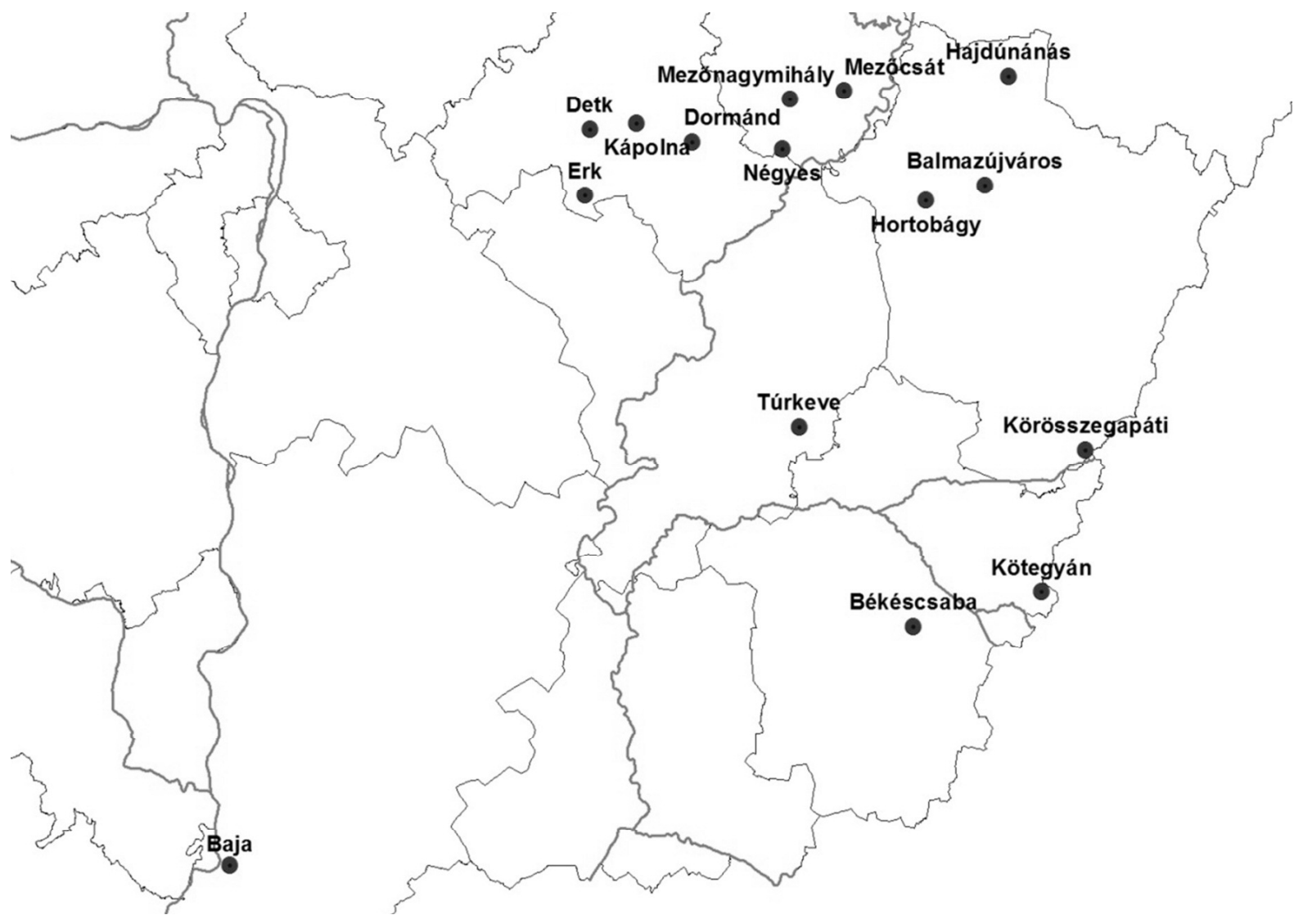


D-loop from GenBank to continue our analysis with. Since the majority of those sequences were shorter with almost 100 base pairs there have been produced two different alignment sets to avoid the loss of information on the Hungarian population. The first alignment of our 39 samples is 410 bp long. The 331 bp long second alignment contains 156 GenBank sequences along with an Oryctolagus cuniculus (Linnaeus 1758) sequence which was used as an outgroup for constructing a phylogenetic tree. DnaSP 5.10 software (Rozas et al. 2003, Librado and Rozas 2009) was used to calculate main diversity indices, Network 4.613 (fluxus-engineering. com) and MEGA 6.06 (Tamura et al. 2013) to build phylogenetic trees, and MEGA 6.06 to calculate TamuraNei distance among populations.

\section{RESULTS}

Our analysis revealed $\mathrm{h}=17 \mathrm{mtDNA}$ D-loop haplotypes among the $\mathrm{N}=39$ Hungarian $L$. europaeus individuals of which 8 were unique (i. e. consisting of only one individual). Based on the 410 base pairs long alignment set a markedly high value of haplotype diversity of $\mathrm{Hd}=0.879 \pm 0.044$ (Table 2) was described along with the nucleotide diversity of $\pi=0.01166 \pm$ 0.0022 . There were identified $S=30$ polymorphic sites in the sequences.

Table 2.

Main diversity indices of the Hungarian Lepus europeaus Pallas 1778 population

\begin{tabular}{lc}
\hline Number of samples & 39 \\
Number of detected haplotypes $(\mathrm{h})$ & 17 \\
Haplotype diversity $(\mathrm{Hd})$ & $0.879 \pm 0.044$ \\
Nucleotide diversity $(\pi)$ & $0.01166 \pm 0.0022$ \\
Number of polymorphic sites $(\mathrm{S})$ & 30 \\
Average number of nucleotide differences $(\mathrm{k})$ & 4.768
\end{tabular}

Based on the alignment a maximum likelihood tree was generated using the Hasegawa-Kishino-Yano model (Hasegawa et al. 1985) with the software MEGA 6.06 (Figure 2). This tree shows a separate clade of two of the haplotypes being genetically farther away from the rest, however they are not separated geographically.

Figure 2: Maximum likelihood tree of the Hungarian samples based on HKY+G model

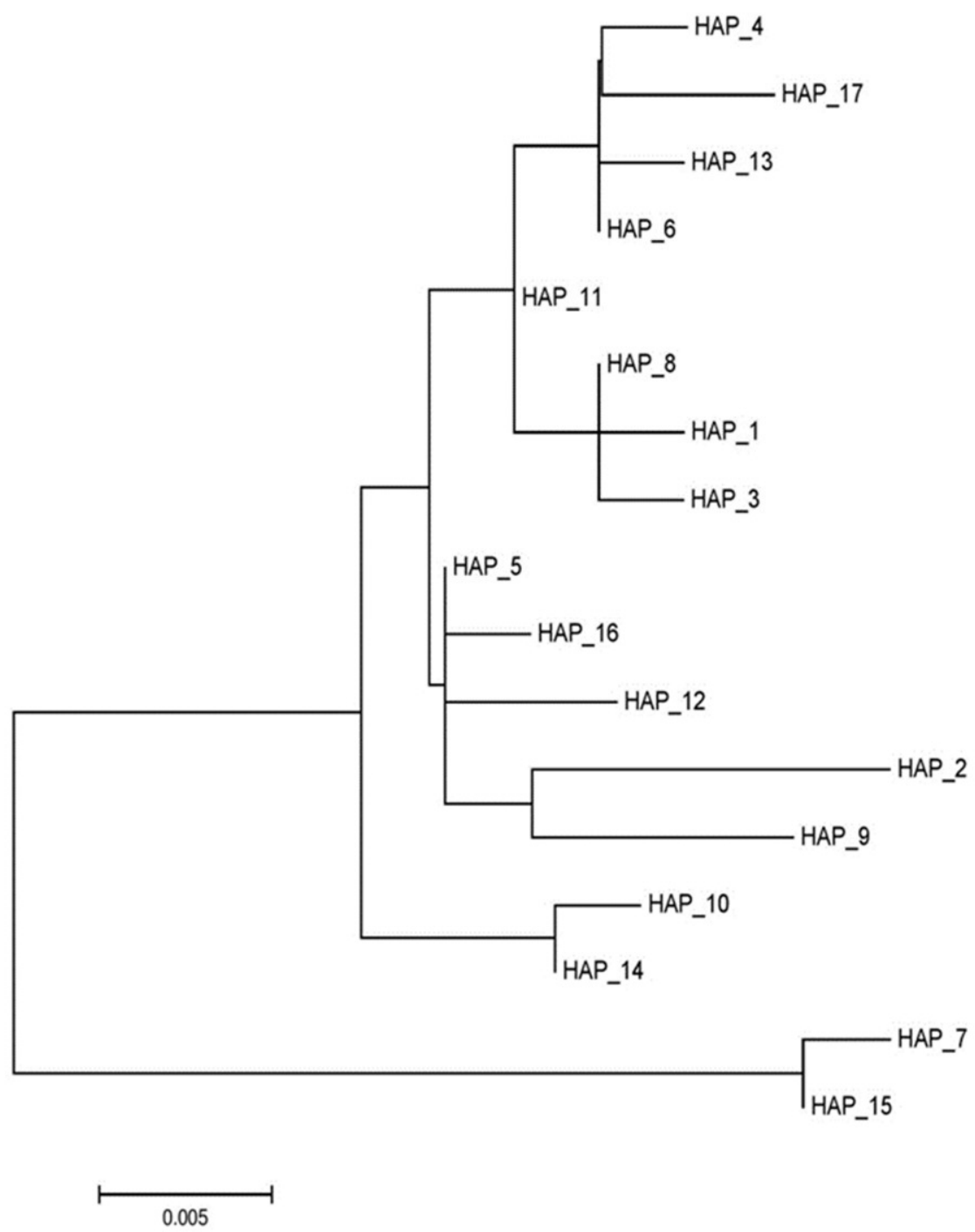


Our second, 331 base pairs long alignment included 156 GenBank sequences from Greece, Italy, Austria, and Germany. An Oryctolagus cuniculus (Linnaeus 1758) sequence (Accession number: AJ535793) was added to the alignment as an outgroup in phylogenetic tree constructions. Two phylogenetic trees have been constructed based on the 112 haplotypes we have got. A median joining tree (Bandelt et al. 1999) which was built using the software Network 4.613 (fluxusengineering.com) reveals a noticeable geographic separation among the inspected haplotypes however the Hungarian population shows itself being genetically close to the Italian and German ones (Figure 3).

Figure 3: Median joining network of the Hungarian and GenBank sequences

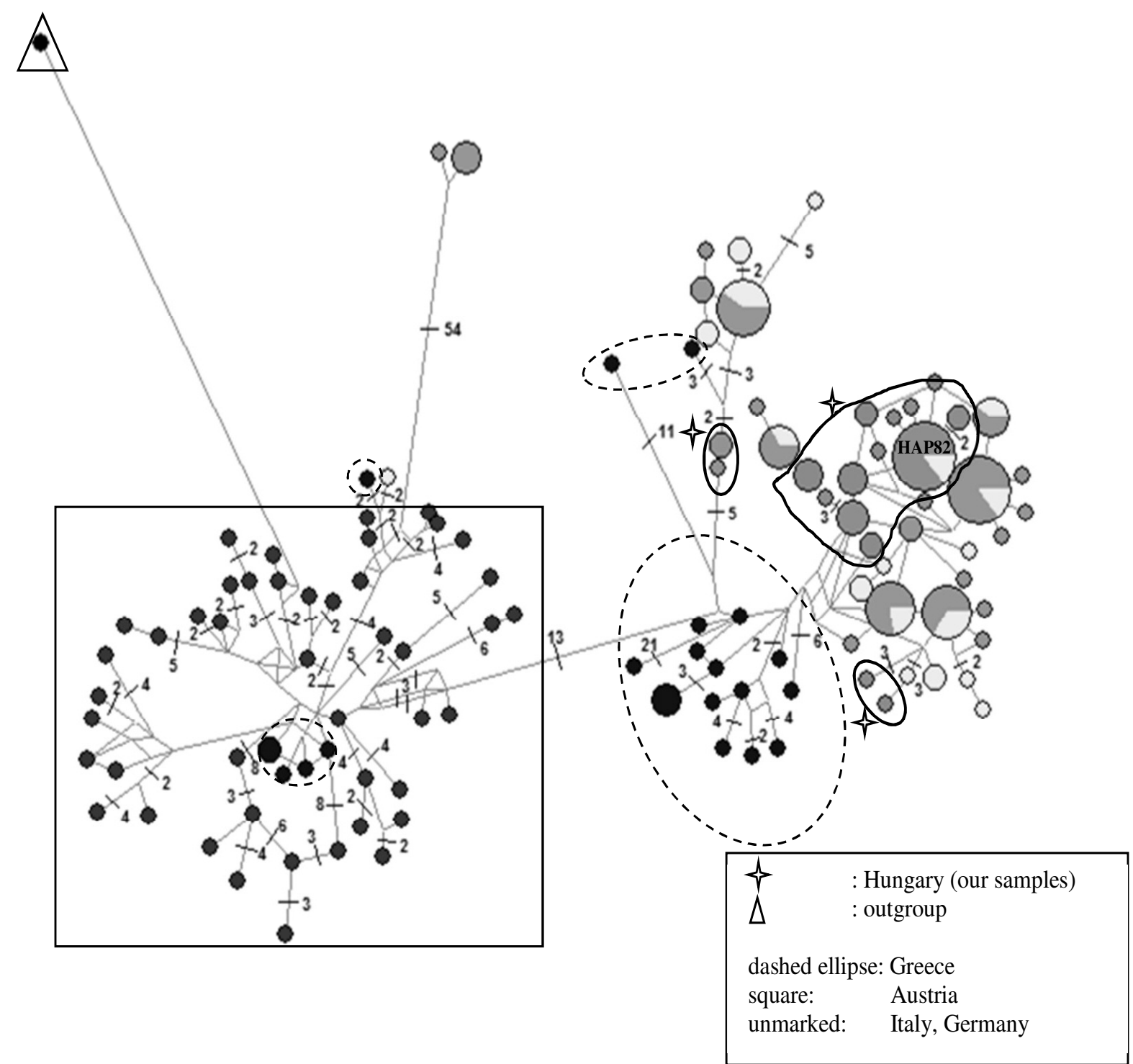

Note: a circle represents a haplotype. Circle sizes are proportional to the number of individuals with the specific haplotype in the total sample. Branch lengths are not proportional to genetic distance. Number of mutational steps between haplotypes denoted. Unmarked branches represent one mutational step. Outgroup: Oryctolagus cuniculus (Linnaeus 1758)

Moreover there is a haplotype (HAP82) consisting of both Hungarian and German sequences. The maximumlikelihood tree $(\mathrm{HKY}+\mathrm{G})$ constructed in MEGA 6.06 illustrates the relationships of haplotypes similarly (Figure 4). Both of the trees show the two previous mentioned Hungarian haplotypes being fairly distinct from the rest on a branch of German, Italian and Greek haplotypes. However none of the Hungarian samples are closely related to Austrian ones. The Tamura-Nei matrix (Tamura and Nei 1993) computed with MEGA 6.06 supports these findings. It shows that the German population is the closest and the Austrian is the farthest from the Hungarian despite their geographic positions (Table 3). 
Figure 4: Maximum-likelihood tree (HKY+G) of 112 L. europaeus mtDNA D-loop haplotypes Oryctolagus cuniculus (Acc. no.: AJ535793) as outgroup

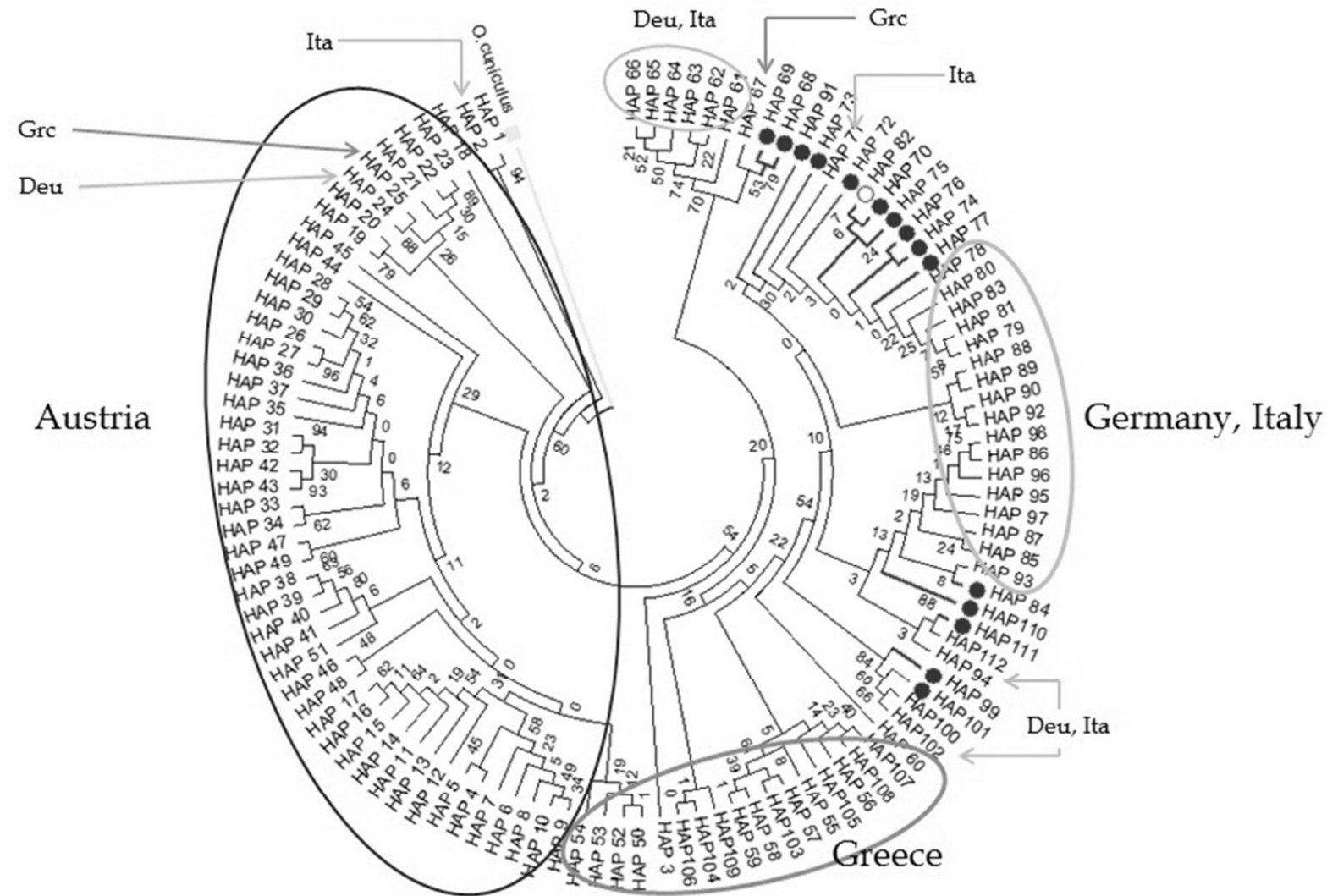

Note: rounds: Hungarian haplotypes, Circle (HAP82): haplotype consisting of both Hungarian and German sequences.

Table 3. Estimates of Evolutionary Divergence over Sequence Pairs between Populations

\begin{tabular}{lccccc}
\hline & ITA & GRC & AUT & DEU & HUN \\
\hline ITA & & 0.0087 & 0.0142 & 0.0073 & 0.0063 \\
GRC & 0.0716 & & 0.0108 & 0.0085 & 0.0079 \\
AUT & 0.1050 & 0.0765 & & 0.0138 & 0.0144 \\
DEU & 0.0545 & 0.0642 & 0.0985 & & 0.0068 \\
HUN & 0.0446 & 0.0532 & 0.0894 & 0.0411 & \\
\hline
\end{tabular}

Note: numbers of base substitutions per site from averaging over all sequence pairs between groups are shown. Analyses were conducted using the Tamura-Nei model. Evolutionary analyses were conducted in MEGA6. SE estimates calculated (above diagonal) with 1000 bootstrap repetitions.

\section{DISCUSSION}

In spite of the fact that many molecular genetic studies have provided a large amount of data concerning the diversity and phylogeography of the L. europaeus in Europe, our knowledge is shallow regarding its Central-European populations. Information can be found in literature on Austrian (Hartl et al. 1993) and Serbian (Vapa et al. 2002, 2007, Djan et al. 2004, 2006) populations but except for a few haplotypes (Pierpaoli et al. 1999) no information can be reached on the Hungarian brown hare populations' diversity. Therefore with our research we intend to gather data on the diversity and reveal the evolution history of $L$. europaeus populations in the Carpathian-basin. Our results shall help to understand the shaping effects of the genetic structure of the species in the region, which is crucial in carrying out preservation and management plans.

The haplotype diversity described in this work is in congruence with the values given forth in previous studies (e.g. Fickel et al. 2008, Stamatis et al. 2009, Mengoni 2011) regarding different populations of Europe. A high level of haplotype diversity $(\mathrm{Hd}=0.853)$ with a great number of haplotypes has been described for example from Greece also by Mamuris et al. (2001). However the haplotype diversity in Denmark (Andersen et al. 2009), Serbia (Djan et al. 2006) and some other regions of Central-Europe (Hartl et al. 1993) was described to be lower. Our preliminary results show that the Hungarian brown hares are more closely related to both Italian and German populations than to Austrian ones. The reason for this could be either the Central-European populations' Italian origin as described by Fickel et al. (2008), or the regular translocations of the 1900s from Central-Europe with the aim of repopulating the over-hunted European habitats (Pierpaoli et al. 1999). Assuming that the close genetic relationship between the Italian and Hungarian populations is resulting from the latter we cannot rule out the possibility that Hungarian populations evolved from the supposedly main post-glacial refugium on the Balkan-peninsula as Stamatis and co-workers suggested (2009). 
However since data on diversity of the brown hare's populations are scarce from the region we don't intend to further speculate until more information is available on the topic.

Molecular genetic studies provide useful data for conservation biology researches which makes possible the further analyses of important diversity related problems. Results of those researches furthermore contribute to creating successful sustainable management plans. Keeping natural populations' genetic variability at a high level is crucial especially in the case of species that live in shrinking natural habitats and are as overhunted and translocated over the times as the brown hare.

\section{ACKNOWLEDGEMENTS}

This project was supported by the János Bolyai Research Scholarship of the Hungarian Academy of Sciences. Furthermore we thank for the help of the Hungarian Ornithological and Nature Conservation Society (MME) - ,, Conservation of Imperial Eagles in Hungary” (LIFE10NAT/HU/019) and „A szalakóta védelme a Kárpát-medencében" (LIFE13/NAT/HU/ 000081) projects.

\section{REFERENCES}

Alves, P. C.-Ferrand, N.-Suchentrunk, F.-Harris, D. J. (2003): Ancient introgression of Lepus timidus mtDNA into L. granatensis and L. europaeus in the Iberian Peninsula. Molecular Phylogenetics and Evolution. 27: 70-80.

Alves, P. C.-Melo-Ferreira, J.-Branco, M.-Suchentrunk, F.-Ferrand, N.-Harris, D. J. (2008): Evidence for genetic similarity of two allopatric European hares (Lepus corsicanus and L. castroviejoi) inferred from nuclear DNA sequences. Molecular Phylogenetics and Evolution. 46: 1191-1197.

Andersen, L. W.-Fredsted, T.-Wincentz, T.-Pertoldi, C. (2009) Brown hares on the edge: Genetic population structure of the Danish brown hare. Acta Theriologica. 54. 2: 97-110.

Antoniou, A.--Magoulas, A.-Platis, P.-Kotoulas, G. (2013): Assessing the genetic landscape of a contact zone: the case of European hare in northeastern Greece. Genetica. 141: 23-40.

Bandelt, H-J.-Forster, P.-Röhl, A. (1999): Median-joining networks for inferring intraspecific phylogenies. Molecular Biology and Evolution. 16: 37-48.

Djan, M. R.-Vapa, L. B.-Obreht, D. R.-Vapa, M. M.-Šelmić, V. R. (2004): On gene pool divergence of the brown hare (Lepus europaeus, Pallas) in Vojvodina. Proc. Nat. Sci. Matica Srpska Novi Sad. 107: 13-20.

Djan, M.-Obreht, D.-Vapa, L. (2006): Polymorphism of mtDNA regions in brown hare (Lepus europaeus) populations from Vojvodina (Serbia and Montenegro). European Journal of Wildlife Research. 52: 288-291.

Endler, Z.-Jezierski, W. (1995): The structure of habitats and the diet of hares. Hare - International Symposium. Czempiń (1992) Polski Związek Łowiecki. Warszawa. (In Polish) 231-245.

Fickel, J.-Hauffe, H. C.-Pecchioli, E.-Soriguer, R.-Vapa, L.-Pitra, C. (2008): Cladogenesis of the European brown hare (Lepus europaeus Pallas, 1778). European Journal of Wildlife Research. 54: 495-510

Folitarek, S. S. (1940): Geographic distribution of the European hare Lepus europaeus Pall. in the USSR. Proc. Severetsov's Inst. Evol. Morphol. Acad. Sci. USSR. 1: 79-97.

Fontanesi, L.-Tazzoli, M.-Beretti, F.-Russo, V. (2006): Mutations in the melanocortin 1 receptor $(M C 1 R)$ gene are associated with coat colours in the domestic rabbit (Oryctolagus cuniculus). Animal Genetics. 37: 489-493.

Fontanesi, L.-Forestier, L.-Allain, D.-Scotti, E.-Beretti, F.-DeretzPicoulet, S.-Pecchioli, E.-Vernesi, C.-Robinson, T. J.-Malaney, J. L.-Russo, V.-Oulmouden, A. (2010) Characterization of the rabbit agouti signaling protein $(A S I P)$ gene: Transcripts and phylogenetic analyses and identification of the causative mutation of the nonagouti black coat colour. Genomics. 95: $166-175$.
Hartl, G. B.-Suchentrunk, F.-Nadlinger, K.-Willing, R. (1993): An integrative analysis of genetic differentiation in the brown hare Lepus europaeus based on morphology, allozymes, and mitochondrial DNA. Acta Theriologica. 38. 2: 33-57.

Hasegawa, M.-Kishino, H.-Yano, T. (1985): Dating of human-ape splitting by a molecular clock of mitochondrial DNA. Journal of Molecular Evolution. 22. 2: 160-174.

Hewitt, G. M. (1999): Postglacial re-colonization of European biota. Biological Journal of the Linnean Society. 68: 87-112.

Kasapidis, P.-Suchentrunk, F.-Magoulas, A.-Kotoulas, G. (2005): The shaping of mitochondrial DNA phylogeographic patterns of the brown hare (Lepus europaeus) under the combined influence of Late Pleistocene climatic fluctuations and anthropogenic translocations. Molecular Phylogenetics and Evolution. 34: 55-66.

Koutsogiannouli, E. A.-Moutou, K. A.-Stamatis, C.-Mamuris, Z (2012): Analysis of $M C 1 R$ genetic variation in Lepus species in Mediterranean refugia. Mammalian Biology. 77. 6: 428-433.

Koutsogiannouli, E. A.-Moutou, K. A.-Stamatis, C.-Walter, L.-Mamuris, Z. (2014): Genetic variation in the major histocompatibility complex of the European brown hare (Lepus europaeus) across distinct phylogeographic areas. Immunogenetics. 66: 379-392.

Librado, P.-Rozas, J. (2009): DnaSP v5: A software for comprehensive analysis of DNA polymorphism data. Bioinformatics. 25: 1451-1452.

Mamuris, Z.-Moutou, K. A.-Stamatis, C.-Sarafidou, Th.-Suchentrunk, F. (2010): Y DNA and mitochondrial lineages in European and Asian populations of the brown hare (Lepus europaeus) Mammalian Biology. 75: 233-242.

Mamuris, Z.-Sfougaris, A. I.-Stamatis, C. (2001): Genetic structure of Greek brown hare (Lepus europaeus) populations as revealed by mtDNA RFLP-PCR analysis: Implications for conserving genetic diversity. Biological Conservation. 101. 2: 187-196.

Mengoni, C. (2011): Phylogeny and genetic diversity of Italian species of hares (genus Lepus). PhD thesis. University of Bologna. Italy.

Panek, M.-Kamieniarz, R. (1999): Relationships between density of Brown hare (Lepus europaeus) and landscape structure in Poland in years 1981-95. Acta Theriologica. 44: 67-75.

Pierpaoli, M.-Riga, F.-Trocchi, V.-Randi, E. (1999): Species distinction and evolutionary relationships of the Italian hare (Lepus corsicanus) as described by mitochondrial DNA sequencing. Molecular Ecology. 8: 1805-1817.

Rozas, J.-Sánchez-DelBarrio, J. C.-Messeguer, X.-Rozas, R. (2003): DnaSP, DNA polymorphism analyses by the coalescent and other methods. Bioinformatics. 19: 2496-2497. 
Stamatis, C.-Suchentrunk, F.-Moutou, K. A.-Giacometti, M.Haerer, G.-Djan, M.-Vapa, L.-Vukovic, M.-Tvrtković, N.Sert, H.-Alves, P. C.-Mamuris, Z. (2009): Phylogeography of the brown hare (Lepus europaeus) in Europe: a legacy of southeastern Mediterranean refugia? Journal of Biogeography. 36: 515-528.

Tamura, K.-Nei, M. (1993): Estimation of the number of nucleotide substitutions in the control region of mitochondrial DNA in humans and chimpanzees. Molecular Biology and Evolution. 10: $512-526$.

Tamura, K.-Stecher, G.-Peterson, D.-Filipski, A.-Kumar, S. (2013): MEGA6: Molecular Evolutionary Genetics Analysis Version 6.0. Molecular Biology and Evolution. 30: 2725-2729.
Tapper, S. C.-Barnes, R. F. W. (1986): Influence of farming practice on the ecology of the brown hare (Lepus europaeus). Journal of Applied Ecology. 23: 39-52.

Thenius, E. (1980): Grundzüge der Faunen- und Verbreitungsgeschichte der Säugertiere. Eine Historische Tiergeographie. Gustav Fischer Verlag. Stuttgart.

Vapa, L.-Obreht, D.-Vapa, M.-Selmic, V. (2002): Genetic variability in brown hare (Lepus europaeus) populations in Yugoslavia. Zeitschrift Fur Jagdwissenschaft. 48: 261-266.

Vapa, L.-Djan, M.-Obreht, D.-Hammer, S.-Suchentrunk, F. (2007): Allozyme variability of brown hares (Lepus europaeus) from the Vojvodina (Serbia), compared to central and south eastern European populations. Acta Zoologica Academiae Scientiarum Hungaricae. 53: 75-87. 
